\title{
With Dreams in Our Hands: An African Feminist \\ Framing of a Knowledge-Making Project with Former ESP Students
}

\author{
Corinne Knowles \\ https://orcid.org/0000-0002-6165-2104 \\ Rhodes University, South Africa \\ c.knowles@ru.ac.za
}

\section{Abstract}

This article introduces a research project that works with former Extended Studies Programme students to make knowledge that emerges through online, multimodal collaborations. Knowledge-making is not politically neutral, and the project and article are responding in part to the calls of the 2015/2016 South African student protesters to decolonise and transform university curricula. The project draws on African feminist ideas, emphasising the intersectional oppressions of colonialism, capitalism and patriarchy, which continue to influence theoretical choices in the knowledge hierarchies of South African and African universities. The "race", class and gender inequalities that drive success or failure at university and in society become some of the topics addressed in the project, where former students as co-researchers collaborate to devise the topics, responses, and kinds of dissemination. Ntseane's overlapping principles of a collective worldview, spirituality, a shared orientation to knowledge, and communal knowledge-making are motifs that influence how the project is imagined and run. My positionality as lead researcher and former lecturer of the co-researchers is navigated using African feminist guidance, which also informs the ethical principles of the project.

Keywords: African feminisms; decolonial knowledge-making; intersectionality; positionality

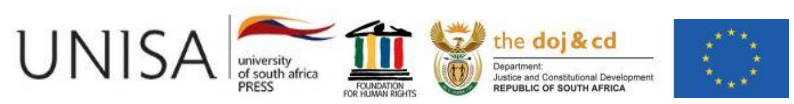

Education as Change 


\section{Introduction}

Every year, students arrive in the Humanities Extended Studies Programme ${ }^{1}$ (ESP) at the South African university where I lecture with dreams and hopes for a better life. The project I introduce is a collaboration with former ESP students to explore knowledgemaking and produce knowledge that we believe provides new ideas in the field of higher education and promotes different ways of teaching, learning and doing research. The theoretical framing sets up a methodology that conspires to work with participants as co-researchers in the multimodal project, with collective agency over the questions asked, how they should be answered, and how they can be disseminated. This deliberate framing imagines a platform for knowledge-making that centres student voices to contribute insights into the kinds of teaching and research that would be decolonised and inclusive.

The 2015/2016 student protests in South Africa were an important moment that marked the public outcry from students who struggled with the costs and content of university education. They highlighted some of the challenges of poor black ${ }^{2}$ students (Department of Higher Education and Training [DHET] 2017; Moloi, Makgoba, and Miruka 2017) concerning the unequal effects of colonialism, patriarchy, capitalism and neoliberalism, which distribute their rewards filtered through socially constructed human attributes such as "race", class and gender. In part, this research project aims to honour the calls of student protesters (characterised in Twitter feeds \#FeesMustFall, \#RhodesSoWhite, \#RUReferenceList) and pays attention to the inequalities that continue to shape the daily lives and the success rate of students based on these constructions. ${ }^{3}$ While university fees did fall for a while (DHET 2017) along with, increasingly, state support (McLaren and Struwig 2019), the more important call for pedagogic and curricula transformation has been unevenly realised between and within universities - and has now been complicated and exacerbated by a global pandemic. A number of ESP students were

1 At the university currently known as Rhodes, the Humanities Extended Studies Programme invites students into the programme based on a number of criteria, including matric marks that fall short of automatic entry into the Bachelor of Arts (BA) or Bachelor of Social Science (BSS) degrees, being the first in their family to go to university, and having received township or rural schooling. They are required to select one of two streams. Those I teach have selected Politics 1 and Sociology 1 as their mainstream subjects. They are taught computer and academic literacies, and most of our work involves the augmentation and literacies of their mainstream courses. The class size ranges between 30 and 45 students.

2 To use the term "black" to define the "race" of students is contested and complicated. It dates back to Steve Bantu Biko's Black Consciousness work during South African apartheid to reclaim blackness as a subjectivity in contrast to the divisive apartheid categories under the umbrella of "non-white" (see Mahlangu 2012). Former students who are part of the project self-identify as "black".

3 South African students' completion and pass rates are "raced" and classed. Recently, Jeynes (2020), of Africa Check, reported that "the completion rate for white students was vastly higher, at $71.6 \%$. Black students had a $53.5 \%$ completion rate and coloured students a $53.8 \%$ completion rate. Asian students came in at $62.1 \%$ ". Student protesters wrote about experiences of racism and frustration with a Western curriculum (see Daniels 2015; Erskog 2015). 
part of the protests at the university currently known as Rhodes (UCKAR),${ }^{4}$ and some of them are part of this project. It is an opportunity for us to apply politically rigorous scholarship (Borras 2016) in response to the calls to change how we think about knowledge-making on the continent, to be representative, relevant, and transformational.

In line with this, this article argues for a Black/African ${ }^{5}$ feminist framing of the research question and project, the positionality of the lead researcher, and the analysis of the data in collaboration with co-researchers. The theories we use shape how we collect, produce, and analyse data in institutions that make certain kinds of knowledge-making feasible (Adomako Ampofo 2010; Appiah 2006; Moletsane 2015). African feminisms provide a lens that allows us to see not only how the knowledge economy in many South African universities is structured to limit the success of young black people and women (Linden 2017; Pather 2018; Skade 2016), but also how new possibilities to flourish can be opened for those who are marginalised in the current system by the intersectional and mutually constitutive oppressions of patriarchy, colonialism, and capitalism.

African feminist principles, I will explain, direct how I as a researcher position myself in relation to the community that shapes the project. I will clarify how the Covid-19 pandemic has become a vehicle for the knowledge-making and what the challenges and opportunities are in the consequential shift in how I originally anticipated the unfolding of the project. I describe the methodological steps of the project and reveal some of the early reflections of the process. As part of the ethical considerations for the project, when I use the words of the co-researchers, they will give permission and we will discuss how their words are used. I purposefully do not use their words in this introduction to the project but focus instead on how the theory helps to construct a methodology that is a platform for knowledge-making with former students. Later papers, including those co-written with co-researchers, will present findings and centre the voices of the former students.

\section{Choosing a Theory}

The theories that we as academic researchers use in our research guide the way we approach knowledge-making (Adomako Ampofo 2010; Appiah 2006; Moletsane 2015). In African universities, as Wane $(2008,193)$ argues, teaching and research take place "within the context of a history of colonialism, imperialism, and neo-colonial, postcolonial and anti-colonial conditionalities". Many have written on the frustrations and

4 Rhodes University was renamed the University Currently Known as Rhodes (UCKAR) by protesters and allies during the 2015/16 student protests. In 2018, following a decision by the Rhodes University Council to halt any consultative process around renaming, and instead to keep the name, some are using the acronym USKAR - the University Still Known as Rhodes. See Daniels (2015) for the argument to change the name.

5 Black feminism and African feminisms have many overlaps and some differences (see Salo and Mama 2001). While African feminisms are predominantly used in this study, African-American feminists also contribute ideas that align to African feminisms. 
dangers of Eurocentric influences on our knowledge-making (Lundgren and Prah 2010; Moletsane 2015). Choosing an African theory is a disruption to the homogeneity of Eurocentric thinking to orientate and enable a process where student voices are central in the process. Blay $(2008,60)$, drawing on the work of Asante, explains how this orientation works:

The degree to which research is Afrocentric is often determined by the researcher's location, or centricity/centeredness, which informs the language s/he employs, the direction of his/her sentiments, themes, and interests, as well as his/her attitude toward certain ideas, persons, or objects. Thus, it is when, and only when the researcher's language, direction, and attitude are centered within an "African cultural territory" that it qualifies as Afrocentric.

As an older white woman in South Africa, given the country's colonial and apartheid history, I am awkwardly located off-centre of Afrocentric in terms of my "race", class and gender. Later in the article I grapple with this positioning to understand and undertake a process of decolonising my own thinking and being in the world. As a teacher and researcher, I am interested in the ways in which the politics of "race", class and gender play out in the knowledge hierarchies that continue to shape who teaches, and what they teach.

The kinds of theorists that undergraduate students are exposed to (for instance in Sociology at the university where I have taught for 11 years) are disproportionately white, male, Western and elite. The same can be said for numerous postgraduate courses I have taken at UCKAR. How relevant are these theories in a South African context? Tamale (2020, 43-44) argues that:

[G]iven the history of the continent and the lingering legacies of colonialism, imperialism, racism and neoliberalism, theories and paradigms formulated in the West do not necessarily apply in Africa. It also underscores the need to develop alternative schools of thought and counter-hegemonic narratives that expose the subtle and intricate power relationships embedded in mainstream theories.

Wane $(2008,185)$ explains that being taught from a European canon caused her "to be disassociated from and devalue the cultural knowledges and wisdom of [her] ancestors, [her] community, and [her] family". Alienation and disassociation are even more likely at a time of national pandemic lockdown, given the huge changes, such as digital teaching and learning, and a loss of connection for many. The aim of the project is to reveal adapted and expanded ways of knowing that restore connectedness. Its intention is to think through the principles of knowledge-making from a perspective that imagines a future that is unpicked from a patriarchal and colonial past. Tamale $(2020,30)$ explains that this "is a multifaceted, holistic and integral process" made more complex because of the pervasiveness of colonialism's legacy, resulting in a situation where "many in mainstream academia, even today, are yet to be convinced that feminist methodologies, approaches and analyses in research are part of legitimate scientific inquiry" $(2020,47)$. 
I have taken this observation to heart by using African feminisms as the theoretical frame.

African feminisms grew as alternative contributions to the conversation about gender in response to the way in which white feminism, and, despite many overlaps, even Black feminism (Salo and Mama 2001), failed to articulate and recognise African realities regarding, for example, decolonisation struggles (Tamale and Oloka-Onyango 1995) and the different significance of gender in some African societies (Amadiume 1987; Oyěwùmí 1997). Even though, for centuries, African women struggled against patriarchy (Salami 2013), it was not known as "feminism", resulting in some resistance to the term among African women (Lewis 2010; Motlafi 2015). But through several iterations over the last few decades strong ideas have emerged that clarify some of the fundamental ideas of what African feminisms are, rather than what they are not. African feminisms foreground gender as a tool for analysis, and locate that in a collective, where the aims of gender transformation are to bring about a better world for all.

African feminist theory has many strands and is more than a set of ideas about the experiences of black women and men. Mekgwe warns against simplistic gender binaries and reminds us that "women do not easily fall into neat categories" (Mekgwe 2007, 21). Ahikire claims $(2014,8)$ that African feminisms are a "myriad of various theoretical perspectives emanating from the complexities and specifics of the different material conditions and identities of women" and how they resist oppression and navigate power. While African feminist theory is developed by diverse women and scholars from a variety of locations and orientations, there are common threads that are explored or assumed by many of them.

Firstly, there is a dynamic relationship between African feminisms and the women's movements on the continent (Goetz and Hassim 2003; Lewis 2001; Mama 2020), in that their intellectual orientation is the collective struggle against the effects of patriarchy, capitalism and colonialism (Mama 2011). Understanding these forces as interdependent and interlinked is key to transforming society through the lens of intersectionality, which recognises that these "systems of oppression are interwoven and co-produced in complex ways" (Tamale 2020, 66). For this reason, argues Tamale, it is vital to "understand this dynamic and stop thinking of discrimination superficially as residing in separate, neatly-marked compartments. For many disadvantaged social groups, discrimination is an inextricably blended experience" $(2020,66)$. In this project, thanks to the work of Tamale and others, "the epistemic value of intersectionality is that it provides us with a critical lens within which to view the world" (Tamale 2020, 67).

Secondly, while the feminist movement and theory in Africa have undergone shifts and changes over time (Ahikire 2014; Lewis 2010; Salami 2017), another common theme is the fight against the structural erasure of black women, individually and collectively (Gbowee 2011; Masola 2018). Mekgwe (2007) unpacks some of the emphases and complexities in African feminisms, including their aim towards "a positive 
transformation of society such that women are not marginalized but are treated as full citizens in all spheres of life" $(2007,13)$.

Thirdly, Mama $(2011,2)$ describes African feminisms as an ethical "intellectual politics", in that an important aspect of the theory is to locate African experiences within the social politics of their contexts. Ahikire explains that "in African contexts, feminism is at once philosophical, experiential, and practical" $(2014,8)$. Mama laments that despite the potential of African feminisms to transform universities, "the discourse on academic freedom and intellectual responsibility in African universities has rarely yielded ground for feminist ethics" (Mama 2011, 1). The feminist ethics implied here become important guidelines in how the project is set up.

For me, then, African feminisms provide an ethical orientation that opens my thinking about pedagogy and this research project in ways that recognise black young people from their own contexts and perspectives, to make knowledge that is relevant and owned by them. The theory is a lens to see how experiences of gender are intricately linked to "race" and class, and how this affects knowledge-making. African feminists have guided my thinking about ethical research, decoloniality understood through the lens of intersectionality, and have provided principles to direct how I work with young South African black people in the project. Tamale $(2020,67)$ explains that "an intersectional approach is multifaceted, challenging Western hegemonic structures and institutions, including the very nature of knowledge (ontology) and how we access that knowledge (epistemology)".

African feminisms mean different things in different contexts. In fields that have used other frames and theories to shape the academic conversation, African feminisms are the "other" - they perhaps have token value but have not captured mainstream imagination for various reasons (Adomako Ampofo 2010; Moletsane 2015). Using African feminisms to frame this project about knowledge-making is an alternative orientation that seeks to change the status quo. It tries to follow the directive of Tamale that as academic researchers, "we must adopt ethical non-positivist intellectual paradigms that acknowledge subjective interpretation of reality and are commensurate with Indigenous (and feminist) knowledge systems that are nonlinear, nonrational and value-laden" (Tamale 2020, 279).

\section{Principles of African Feminisms that Shape the Project}

The project I introduce in this article is set up for former ESP students to make knowledge together, at a time of a global pandemic that exacerbates the inequalities in our society and university. It is a mixed group of young black women and men, who at some stage between 2011 and 2019 were part of the ESP programme at UCKAR and were taught by me. As such, it works with young black people whose lives are shaped by gender, "race" and class inequalities that are the outcomes of patriarchy, colonialism, and capitalism. In this article I foreground the thinking of African feminists who are marginalised in the knowledge hierarchies in our thinking about pedagogy in the South 
African academy, and I apply their thinking on how to conduct research as I grapple with power relations and ethics in the project. In particular, Ntseane (2011), drawing on Mkabela and Asante, offers principles that run through the work of many African feminists, and that have guided the thinking and planning for the project.

Ntseane (2011) writes from the position of an African woman who acknowledges that even while her being is constituted by her location in the collective, the "reality of marginalization has been pushed further to the periphery due to the gendered contexts defined by the legacy of colonialism" (Ntseane 2011, 308). Her paper explains a project that draws on African and African feminist ideas that resonate with my aims in the project.

Ntseane (2011) argues that the four interconnected ideas that guide an Africanist and African feminist approach to research are a collective worldview, spirituality, a shared orientation towards knowledge, and the role of gender in how knowledge is processed. A collective worldview demands that thinking about the individual, for instance regarding human rights and social justice during a pandemic, is, as Motlafi explains, a "delicate balancing act" between individual and community needs, recognising that "both black men and women continue to struggle with colonial legacies of socioeconomic deprivation" (Motlafi 2015). Wane (2008, 187) explains that African feminisms, overlapping with most African societies, "stress the ideology of communal, rather than individual, values and the preservation of a community as a whole". As Ntseane argues, a sense of the collective shapes people's recognition of what constitutes a problem, and for this reason research on the continent must locate the research community as agents in the research $(2011,312)$ whose worldview becomes the perspective from which the project emerges.

Spirituality is part of the African orientation that Ntseane recognises as important to the collective worldview, in that "the spirit is the ultimate oneness with nature and the fundamental interconnectedness of all things" (Ntseane 2011, 312). Spirituality motivates African feminist politics and intellectual work to be "whole and fight the injustices, positioning the academic as one who fuses within this knowledge the head with the heart to understand the world" (Motsemme cited in Wils 2017). This holistic imperative differs from what Collins $(2003,59)$ calls "Western, either/or dichotomous thought", because "the traditional African worldview is holistic and seeks harmony". Tamale draws on Graham's work to encourage "decolonial activism" through a focus on, among other ideas, the Ubuntu philosophy: "the interconnectedness of all things; the spiritual nature of human beings ... oneness of mind, body and spirit; and the value of interpersonal relationships" (Graham cited in Tamale 2020, 21). The implication is that the researcher is not merely doing intellectual work, but has a responsibility to bring her body, mind and spirit to the process of inclusion and connection that she enables for others. Wane (2008) reminds us that knowledge is embodied, and this affects how knowledge is accessed. Working with former young, black students as part of the project, this will become significant in how we connect with one another, and how the 
interconnections of "race", class and gender affect our knowledge-making. Reconnecting the mind, body and spirit enables the process of connecting to others.

An openness to spirituality in the research process can guide and enhance the direction and legitimacy of the project. It can influence the "holistic sustainability of interconnected ecological systems" of knowledge (Wane 2008, 192) by being mindful of the values, emotions and experiences that co-researchers bring. Feminist writer Malaika Mahlatsi ${ }^{6}$ argues passionately that we resist excluding emotion from our intellectual work:

[E]motion is not lack of reason. The insistence on treating emotion as mutually exclusive from reason is rooted in Westernised formulations of what constitutes valid knowledge and what doesn't. It is used to delegitimise any and all things that don't fit neatly into the box of what it deems credible - such as, for example, indigenous knowledge systems that have often been dismissed as emotional, mythical and superstitious. People can be emotional and rational. It is not mutually exclusive. (Mahlatsi cited in Knowles 2020)

And so, a focus on the whole person as a spiritual imperative is brought into the project in careful collaboration with co-researchers over time. A code of practice is codeveloped to keep open and to enable a deeper listening for the ideas that orientate our thinking and being towards connection and transformation. As the initiator of the project, I am learning to honour my own spiritual and emotional connectedness, and the reflective journal and critical friends I keep as part of the journey are helpful records and reminders of this.

The shared orientation towards knowledge that Ntseane emphasises is threefold. Firstly, it emphasises the fluid nature of knowledge to be shaped by the context in which it emerges. It is not absolute. It is constructed by those who work with it, for particular ends (Ntseane 2011). Secondly, it refers to the function of knowledge to liberate those who work with and produce it. Emancipation is an important feature on a continent and in a country that continues to feel the effects of colonisation, capitalism, patriarchy, and apartheid, for instance in terms of the people and ideas we venerate in universities. For this reason, Adomako Ampofo and Arnfred (2010, 25) explain the purpose of African feminisms as the work of imagining a better future, and to produce and find "the kind of knowledge that allows us to fully understand our divided realities in order to transcend them". The long-term purpose of the project is to create the conditions to reveal new possibilities to co-create knowledge about teaching and learning with students. This practice has the potential to join and develop conversations that will inspire practices of de-investment in the neoliberal model, liberation from a patriarchal,

6 Mahlatsi, writing under the pen name Malaika Wa Azania, is an UCKAR graduate. She recently published Corridors of Death: The Struggle to Exist in Historically White Institutions (2020). The book outlines the mental health crises among black students in universities such as UCKAR. She routinely leaves Facebook for periods and breaks from the thousands of people who follow her there. 
capitalist, and colonial Western framing, and the eradication of harms and oppressions based on "race", class, and gender.

The third aspect of a shared orientation towards knowledge brings together the ideas of liberatory, communal knowledge and spirituality. Ntseane explains that women in her research project that looked at women's transformational learning had the realisation of segakolodi, which means "intuitive guide", or pelo ya bobedi, which means "second heart", as part of the research outcomes. The role of these realisations "was to remind individuals of their purpose on earth, which in their context was to be useful or to give back to the community" (Ntseane 2011, 313). For her, emancipation is conceived as a connection between the past and the future in that a spiritual connection with ancestors and guides could bring about transformation (and liberation) in the community.

Ntseane's fourth principle to guide research methodologies is the role of gender in how knowledge is processed. Critiquing the focus on the individual in Mezirow's transformational learning model, Ntseane points out and gives examples of ways in which her study in Botswana demonstrated that one contribution to knowledge-making that women generate is to make it communal (Ntseane 2011,319, 320). She argues that this orientation to the communal is linked to gender roles, for instance the idea of women as mothers and the strong connection between motherhood and nature; the idea that women are strongly oriented towards labouring collectively (for instance in crop growing and harvesting); and the belief that women are expected to work towards the good and emancipation of the community. These gender role constructions are "not without the usual subtle and hegemonic sexism" (Ntseane 2011, 319), but, as she recommends, "these cultural learning values appeal to community construction of knowledge as opposed to an individual's construction; thus, they offer alternative ways in which adult educators may work with communities" (Ntseane 2011, 320). In the project I will go on to introduce, guided by this principle of communal knowledgemaking, we find ways to work together to create knowledge for the purpose of communal benefit while navigating the hierarchies of "race", class, and gender.

\section{Reasons for Selecting the Site of Research}

I am drawn to African and African feminist theories, and methodologies, because of relationships and connections that are intellectual and emotional. The selection of coresearchers and the site of the project has not been neutral or dispassionate. The questions I ask are germinated from 10 years of connecting with students, as a group and individually. While the project is a response to the calls of 2015/2016 student protests in South Africa (Mkhize 2015; Ngcobozi 2015), it is also about reconnection with former students, in a project that is a platform where dreams, gifts and concerns find expression and are welcome. 
In April 2020, I put out an open call on my Facebook page, ${ }^{7}$ inviting former ESP students to join me in working on a knowledge-making project as part of my $\mathrm{PhD}$. I also asked them to tag friends or recommend to me others who might be interested. I followed up with all those who replied, and with those they recommended, outlining the commitment of the project. The 24 individuals who volunteered for and committed to the project are all former ESP students - half of them are still at UCKAR studying or lecturing, and the remainder are working, unemployed or between jobs/plans. I taught all of them Politics and Sociology extended studies (between the years 2011-2019) to support their success in the mainstream formal curricula. A few of them know one another, but largely the common relationship is with me. As I explain later, this has important implications for how I manage my power to enable a collective worldview and shared orientation to knowledge.

My pedagogy is based on hooks's liberatory, humanising, transgressive learning (hooks 1994). Through class and group discussions (in English and isiXhosa), numerous feedback opportunities (anonymous and named), and individual meetings with students (voluntary and compulsory), the students and I get to know each other well in the year that I teach them. They give me insight into their lived experience, their backgrounds, their knowledges, and I work hard to be aware of how power is distributed in the lecture room in order to undermine my own power and to encourage mutual vulnerability as a pedagogic and humanising strategy (Knowles 2014 a). I expose them to African feminist ideas, noticing the intersection of "race", class, and gender oppressions. Many students maintain their relationship with me (by visiting, writing, or via social media) long after they have left the Extended Studies Programme or graduated.

My pedagogic strategies in the Extended Studies Unit are to build shared knowledge and mutual trust; to establish a community of practice, where we feel a sense of responsibility for each other as well as ourselves; to encourage critical thinking from a South African, localised perspective, for the common good; and to use the power of imagination to apply theory and knowledge to potential real-life situations (Knowles 2014b).

In these and other ways, students who come through my ESP classes already have, to some extent, a lived understanding of the principles of the project. I believe that this sets us up to collaborate. Ntseane reminds us that for her, research requires a special kind of relationship between the researcher and the researched, where "African researchers are not supposed to be objective and remain distant from the person who needs assistance, but rather researchers have to work toward a close and reciprocal relationship" (Ntseane 2011, 312). I argue that the students I teach, and have taught, and who teach me, have ways of knowing and being that can expand our current canons and

7 Many former and current students are Facebook friends, and my account is open, which means that even those who are not friends can access my page. I asked those who accessed my page to recommend others who might be interested in the research project. 
pedagogies. The project's aim is to find ways, with former ESP students, that enable them to benefit collectively.

\section{Positionality of the Researcher in Relation to the Research Community}

As a white, middle-class woman, I have the privilege to access public and private goods in the face of profound inequality in South Africa. The students I teach have gifts to give and dreams to realise, but are given only limited access to how public goods, such as universities, are configured. A focus on numbers and quotas and on a neoliberal framework purposefully accepts a majority of students categorised as black and poor, and yet in formerly white institutions such as UCKAR they are precisely the ones most likely to fail (Pather 2018). Even when qualified, they are the least likely to be hired (Diale 2019; Skade 2016).

Concern about the positionality of the researcher requires noticing ways in which power is distributed in the project, and what researcher biases and orientations influence the outcomes and benefits of the research. Because knowledge-making is never politically neutral (Appiah 2006), and because I claim to work with participants as co-researchers with agency, I have to put things in place that will provide the project with checks and balances to legitimise the knowledge we make. As lead researcher in the project, and former lecturer of the co-researchers, I inevitably have the balance of power, which I must navigate responsibly alongside my co-researchers. The privileges afforded to me by the structural benefits of my "race", class and age could blind me to the realities of my co-researchers because I do not share their lived experience and my thoughts and actions could bear the traces of residual and insidious prejudice. Few $(2007,460)$ generously argues that in "using a Black feminist or critical race feminist theoretical lens, how the standpoint is articulated matters more than the color of the researcher". She claims that it is our motivation for the project and for the groups we choose that will shape the relationship between the researcher and the research community. Is "motivation" enough to liberate knowledge-making beyond my limited perspectives?

Using African theories as a white woman, the daughter of missionaries, to do research among black former students, risks re-inscribing the power arrangements that for centuries have plundered Africa as a site for extraction (Grosfoguel 2020). As Carstensen-Egwuom $(2014,269)$ points out, "[t]his means that an awareness of a (possibly privileged) position before entering the field may be helpful, but a reflection upon experiences during fieldwork can show how such a position is negotiated, questioned, or challenged". For this reason, I am compelled to consider my position beyond mere intentions and motivations, reflecting more on "the interactional, relational and power dynamics of the research at hand, rather than focusing on a confession of emotional or discursive positionings of the individual researcher" (MacCleod in Chiweshe 2018, 77). To hold me to an African feminist orientation, I keep a reflexive account throughout the project (Ellingson 2009, 2017), developing a case record of plans and journal entries for regular reflection. I have critical friends with whom I discuss aspects of the project and how I feel about them, regular discussions with my 
supervisor, and an African feminist reading group that keeps reminding me of the principles I aspire to live by. These and other measures are in place to undermine the default positions of whiteness, so that I am able to work with former students with integrity, openness and care. Despite this, I acknowledge the effectiveness of privilege at hiding its own operations (Matthews 2011). I am guided by the prophetic words of Adomako Ampofo (2010, 28):

[M]aintaining commitment to core feminist goals in one's scholarship and praxis provides the strength needed to carry on scholarship and praxis in a context where the exigencies of life so often threaten to crowd out these goals.... I contend that ultimately it is only possible to maintain one's strength as a feminist scholar and activist through constant reflection, both personal and communal.

While in many ways the project integrates my activism, worldview, and pedagogy, it is the students' perspectives, context, worldviews, and the dreams and longings they arrive with that the project will facilitate, honour and commend. There are protocols in place (discussed with the group) for anonymous feedback and for concerns to be raised by the co-researchers, including concerns around my facilitation and power in the process. My aim is a kind of leadership that is reflective, empathic, and ethical (Eze 2015), while enabling a mutually responsible community, and encouraging the visibility of alternative ways of knowing and expressing (Ntseane 2011). hooks discusses the empathy and leadership required in a pedagogy that seeks to liberate, arguing that it "means welcoming the opportunity to alter our ... practices creatively, so that the democratic ideal of education for everyone can be realised" (hooks 1994, 189). The power that I have because of histories of unequal interactions structured around student/teacher, "race", class, and gender can be reworked to be "creative and lifeaffirming" (hooks 1989, 86-87) by consciously embracing African feminist principles and practices in how I work with co-researchers, how I read and enable their responses, and how they experience and shape the project.

\section{Starting the Project during Covid-19}

My intention was to enable the sense of a collective through setting up a space for expressing and listening, calling and responding, so that a shared appreciation and recognition emerges. Mkabela $(2005,185)$ claims that the research community must be part of the research process from beginning to end, so that research outcomes are used to contribute towards community goals and needs in a relevant way, demonstrating a collective sense of the world and/or of the purpose of the knowledge-making between the co-researchers. An immersive, face-to-face weekend workshop at the start of the project would have been an opportunity to demonstrate these principles and open up an understanding of what it means to be co-researchers in a research community. It would have allowed co-researchers to get to know one another through formal and informal activities set up to create a safe space for sharing vulnerability. But as the Covid-19 pandemic swept across the world, it made travel and face-to-face gatherings impossible. 
As was the case with teaching, research projects have had to adapt to the changed conditions necessitated by the pandemic. Despite my experience of and frustrations with online teaching and learning during the first few months of lockdown when Covid-19 reached South Africa, I initially failed to adjust my expectations of a project that was envisaged as a collaboration between people who have developed a sense of the collective. I will explain the phases of the project in more detail, but an important aspect of introducing it is to recognise what was lost, and found, in the reconfiguration of how it unfolded alongside strict lockdown as the pandemic affected life as we know it.

\section{How the Project Works}

The project is conceived in five phases, which are not necessarily linear or discrete:

- the inviting phase,

- the devising phase,

- the creating phase,

- the analysing phase,

- $\quad$ and the disseminating phase.

I have explained the inviting phase, which secured the commitment of 24 people to the project. A dedicated Facebook group (closed to these 24 co-researchers and me) was set up and each participant joined via private message invitation.

The devising phase would have been discussed in the immersive face-to-face workshop over two days at a resort. The project is based on a call-and-response process, where coresearchers respond to topics they have devised and give feedback on each other's work. The shift from a face-to-face workshop at a venue for two days to an online Zoom workshop for two hours was a stark reminder that fostering engagement, liberation and connection as a methodology is not an event, but a process. The pandemic pushed me out of my comfort zone as an engaged, embodied, present and intuitive teacher, into a digital space that was unequally accessed, cold, and constrained by time and data issues. The Zoom workshop was by far inferior to what it could have been, and so began a process of letting go of my methods and identities that resist change. I devised a postworkshop questionnaire that at least gave voice to co-researchers' preferences, reflections and concerns. Moletsane $(2015,45)$ reminds us that "what is needed is the co-reflection with our participants on the research process itself, the power dynamics inherent therein, and the extent to which these tools enable us to challenge and address these so as to pave way for democratic decision making about the strategies needed for social change". The questionnaire was developed with this in mind. In private messages and completed feedback forms, participants reminded me that they remained eager to be part of the project, overwhelmingly because they believed that it could produce new 
knowledge, and that they had contributions to make to it. They gave input on topic suggestions, on which work-teams they wished to be part of (for example, transcribing and translating), and how they felt about participating. They signed consent forms and indicated their understanding of the confidentiality agreements and the voluntary nature of all engagements.

\section{The Creating Phase}

The post-workshop questionnaires delivered a list of 28 topics, and via Facebook polls a final four topics were selected from the list for the first round of submissions. The topics were, broadly: 1 . Confidence/ owning the teaching and learning process; 2 . Looking at how Covid-19 has exposed inequalities in South African universities and/or public schools; 3. What causes mental pathologies among SA university students? 4. What has been the most shocking/interesting discovery about yourself during the Covid19 pandemic?

Co-researchers were invited to respond to one of these four topics. A document devised from workshop and questionnaire inputs on how to respond to a topic was posted onto the Facebook group to guide their engagement. The document explained the range of ways to respond, including in different languages and using different genres, written, voice or video submissions, and the relevance and importance of personal experience. The majority of the co-researchers submitted responses to one of the four questions, and of the 19, all were in English (one was also translated by the author into isiXhosa); all were written pieces; 15 were opinion pieces; one was a letter, and three were academic/research papers.

When we speak or write, our words take on a life of their own beyond the creator. Coresearchers expressed their fears, concerns, hopes, strategies, discoveries, outrages, and observations around the four topics, from their personal perspectives, in the context of the Covid-19 pandemic. Considering their answers and my personal communication with some of them, I acknowledge that they engaged in this process of writing while, along with many South Africans at the time, they were dealing with the stresses of lifepeople falling ill, online learning, unemployment, poverty, health risks at work and home, and increased insecurity and uncertainty.

Enabling a space for people to bring their experiences with the aim of making knowledge that is liberating is perhaps idealistic, but nonetheless necessary, and it is a journey that is always incomplete and being remade. I see it as a profound and important task that needs wisdom, alertness and presence, and constant reflection. It is a process of connecting people around an idea and to one another. Collins, drawing on Belenky et al., argues for "an epistemology of connection in which truth emerges through care", claiming that "connected knowers see personality as adding to an individual's ideas and feel that the personality of each group member enriches a group's understanding" (2003, 64). Two strategies helped with an "epistemology of connection" in response to what I viewed as an inferior and cold Zoom workshop with all the co-researchers to kick off 
the project: the first involved a set of smaller workshops post-submission that allowed co-researchers, in groups of between two and five, to reflect on the experience; and the second was creating a composite piece from all their submissions.

The post-submission workshops were small enough to have video throughout our conversations, and this had an effect of a much freer discussion than the first workshop. Real people with faces were part of a conversation, allowing a space for co-reflection and the reading of power dynamics espoused by Moletsane $(2015,45)$. I told them that all submissions were written in English, despite the freedom to explore other languages. Wane $(2008,188)$ claims that "colonial education had seared [her] consciousness and [she] had become indoctrinated in the belief of meritocracy", and the co-researchers seemed to support this belief. Reflecting after these workshops on what they said about feeling more comfortable writing in English, I realised the more important point not brought up: what they did not say, is that part of it was that I introduced the project in English and am not nearly fluent enough in isiXhosa to hold spontaneous conversations. Reminded of Blay's injunction $(2008,60)$ about the language of the researcher, I recognise how the liberty of co-researchers is limited by the boundaries of my understanding in terms of language, presenting a position to be "negotiated, questioned or challenged" (Carstensen-Egwuom 2014, 269). In the workshop, co-researchers offered ideas on how they should respond to each other's work, and I worked these into a document titled "How to respond to each other's work", and posted it onto the Facebook group, as well as to each co-researcher along with two anonymised submissions for their review. My sense is that the workshops had the effect of getting to know one another better and establishing the principles of empathy and connection that would guide how they reviewed the pieces that were sent to them.

The second strategy to connect co-researchers to one another was to devise a composite piece. I read through each submission and highlighted a sentence or two in each that touched me or indicated what I thought to be their core argument. I then put all the highlighted sentences onto a page and juggled them around to create a composite piece using only the words of the contributors. Wane supports a research methodology where "knowledge is collectively and communally shared, and not monopolized by individuals" $(2008,191)$. hooks $(1989,131)$ argues for a humanising use of dialogue that creates a connection between two subjects, rather than a subject and object arrangement. Collins takes this further to claim that a "primary epistemological assumption underlying the use of dialogue in assessing knowledge claims is that connectedness rather than separation is an essential component of the knowledge validation process" $(2003,59)$. The composite piece, posted on the Facebook group, recognised the unique contributions of each submission and put these together to resemble a dialogue with one another, to show how each one fits into their collective worldview and shared orientation towards knowledge, which are the important African feminist principles that guide the project. 
The co-researchers went on to review one another's work, and then all submissions and reviews (all anonymised) were posted on the Facebook group. A third set of smaller workshops was held where we reflected on the process and discussed ways forward. The co-researchers were given the opportunity to leave the project (one did so, citing a new work opportunity), to work on co-written papers (18 would like this), and to work on other kinds of pieces such as visual art (1 is working on that with me), newspaper articles (11 are interested), or theatre/fiction ( 8 would like to try).

\section{The Ongoing Analysing and Disseminating Phases}

The project generates data from a number of sources, including transcriptions of all the workshops (completed by those of the co-researchers who were interested in this), and all the submissions to the topics and their reviews. Other data sources are contemplated by the contributors to this project that continues to unfold, including recordings of interviews with African feminists that co-researchers undertake and narrative questionnaires or recorded interviews with each participant.

The data generation for this research project serves a number of purposes: as explained, the process aims to place the co-researchers at the centre of the research, with power over their own contributions and what happens to these; and the process assumes that the data generated from it will provide the material for knowledge-making about teaching and learning, and to demonstrate the kinds of knowledge that can be produced when African feminist principles are used in research with former and current students. The project will run for a year, and over time might shift in focus and expression depending on the careful thought and agreement of the co-researchers. Currently, two teams are working on co-writing journal articles on topics they have selected, using the data from their initial submissions. This involves regular online Zoom meetings and tasks we agree to ahead of each one. Another small team of two is working on an art piece. The data generated by the project is the material we use to make knowledge together-about how we know, what we know, and what we are learning in an unprecedented global moment of uncertainty and change presented by the Covid-19 pandemic.

What emerges from the data is the subject for further papers and pieces, worked with collaboratively. How we disseminate the knowledge we make will be collaboratively decided, with permissions from those whose work will be used.

\section{Conclusion}

African feminist theory is a deviation from the theories usually employed to undertake research in the field of higher education. It has been explained as a political and intellectual choice because its end is not only to explain and understand, but also to transform the status quo. Importantly, as Tamale (2020) and Mama (2011) explain, African feminisms seek to dismantle the mutually constitutive "race", class and gender oppressions that arise from colonialism, capitalism, and patriarchy. The project I 
introduce in this article uses an African feminist framing to work with former ESP students whose university life is shaped by the "race", class and gender inequalities they seek to transform. As co-researchers, they have agency over the content and process of the project, which aims to make knowledge that is relevant and transformative, in keeping with the idea of the university as a public good. Although the Covid-19 pandemic interrupted what could have been an immersive weekend workshop to engage co-researchers with the purpose and process of the project, different means were found to develop a sense of the collective: smaller online workshops, individual contact, creating a composite piece from their contributions, and working in small groups on knowledge-making projects. The agency that co-researchers have, to choose the questions that are asked, to choose how to respond to them, and to engage in reflection on this together, is anticipated and enabled by African feminists who believe that members of the research community, as individuals and as a collective, matter. It places the former ESP students in the centre of the ongoing research project, as collaborators in knowledge-making as a contribution to conversations and processes that aim to decolonise the university. Using an African theory in this way sets up a methodology that breaks free from a Western framework to open up expanded ways of knowing that integrate experience, emotion, values and intellect. The project is ongoing. It finds that former ESP students have things to say and ways of being that compel the university to take them seriously, and so we are working together to find a pedagogical innovation that can meaningfully nurture and support the dreams that these students have in their hands when they arrive at the doorstep of the university.

\section{References}

Adomako Ampofo, A. 2010. "One Who Has Truth—She Has Strength: The Feminist Activist Inside and Outside the Academy in Ghana". In African Feminist Research and Activism: Tensions, Challenges, Possibilities, edited by A. Adomako Ampofo and S. Arnfred, 28-51. Uppsala: Nordic Africa Institute.

Ahikire, J. 2014. "African Feminism in Context: Reflections on the Legitimation Battles, Victories and Reversals". Feminist Africa 19: 7-23.

Amadiume, I. 1987. Male Daughters, Female Husbands: Gender and Sex in an African Society. London: Zed Books.

Appiah, K. A. A. 2006. Cosmopolitanism: Ethics in a World of Strangers. London: Penguin.

Adomako Ampofo, A., and S. Arnfred, eds. 2010. African Feminist Politics of Knowledge: Tensions, Challenges, Possibilities. Uppsala: Nordic Africa Institute.

Blay, Y. A. 2008. “All the 'Africans' Are Men, All the 'Sistas' Are 'American', But Some of Us Resist: Realizing African Feminism(s) as an Africological Research Methodology". The Journal of Pan African Studies 2 (2): 58-73. 
Borras, S. M. 2016. "Land Politics, Agrarian Movements and Scholar-Activism". Inaugural Lecture, International Institute of Social Studies, April 14, 2016. Accessed February 8, 2017. http://repub.eur.nl/pub/93021/Jun_Borras_Inaugural_14Apr2016.pdf.

Carstensen-Egwuom, I. 2014. "Connecting Intersectionality and Reflexivity: Methodological Approaches to Social Positionalities”. Erdkunde 68 (4): 265-76. https://doi.org/10.3112/erdkunde.2014.04.03.

Chiweshe, M. 2018. "African Men and Feminism: Reflections on Using African Feminism in Research”. Agenda: Empowering Women for Gender Equity 32 (2): 76-82. https://doi.org/10.1080/10130950.2018.1460088.

Collins, P. H. 2003. "Toward an Afrocentric Feminist Epistemology". In Turning Points in Qualitative Research: Tying Knots in a Handkerchief, edited by Y. S. Lincoln and N. K. Denzin, 47-72. Walnut Creek, CA: Altamira Press.

Daniels, P. 2015. "Rhodes University's Black Student Movement Responds to Jonathan Jansen”. Daily Maverick, March 29, 2015. Accessed June 6, 2018. https://www.dailymaverick.co.za/opinionista/2015-03-29-rhodes-universitys-blackstudent-movement-responds-to-jonathan-jansen/\#.WyEu40iFPIX.

DHET (Department of Higher Education and Training). 2017. Report of the Commission of Inquiry into Higher Education and Training to the President of the Republic of South Africa. Pretoria: DHET. Accessed June 6, 2019.

https://juta.co.za/media/filestore/2017/11/Commission_of_Inquiry_into_Higher_Education _and_Training_Report.pdf.

Diale, L. 2019. "South African Graduates Continue to Struggle Post Graduation". Sunday Independent, May 27, 2019. Accessed June 6, 2020.

https://www.iol.co.za/sundayindependent/south-african-graduates-continue-to-strugglepost-graduation-24189315.

Ellingson, L. L. 2009. Engaging Crystallization in Qualitative Research: An Introduction. Thousand Oaks, CA: Sage Publications. https://doi.org/10.4135/9781412991476.

Ellingson, L. L. 2017. Embodiment in Qualitative Research. New York, NY: Routledge. https://doi.org/10.4324/9781315105277.

Erskog, M. 2015. "Transformation in Action”. Daily Dispatch, April 14, 2015. Accessed June 6, 2018. https://www.dispatchlive.co.za/news/opinion/2015-04-14-transformation-inaction/.

Eze, C. 2015. "Feminist Empathy: Unsettling African Cultural Norms in The Secret Lives of Baba Segi's Wives". African Studies 74 (3): 310-26. https://doi.org/10.1080/00020184.2015.1067996. 
Few, A. L. 2007. "Integrating Black Consciousness and Critical Race Feminism into Family Studies Research". Journal of Family Issues 28 (4): 452-73.

https://doi.org/10.1177/0192513X06297330.

Gbowee, L. 2011. Mighty Be Our Powers: How Sisterhood, Prayer, and Sex Changed a Nation at War. London: Beast Books.

Goetz, A.-M., and S. Hassim, eds. 2003. No Shortcuts to Power: African Women in Politics and Policy Making. Vol. 3. London: Zed Books.

Grosfoguel, R. 2020. "Epistemic Extractivism: A Dialogue with Alberto Acosta, Leanne Betasamosake Simpson, and Sylvia Rivera Cusicanqui”. In Knowledges Born in the Struggle: Constructing the Epistemologies of the Global South, edited by B. De Sousa Santos and M. P. Meneses, 203-18. New York, NY: Routledge.

hooks, b. 1989. Talking Back: Thinking Feminist, Thinking Black. Boston, MA: South End Press.

hooks, b. 1994. Teaching to Transgress: Education as the Practice of Freedom. London: Routledge.

Jeynes, K. 2016. "FACTSHEET: How Many South African Students Graduate?" Africa Check, December 1, 2016. Accessed November 22, 2020.

https://africacheck.org/factsheets/factsheet-many-south-african-students-graduate/.

Knowles, C. 2014a. "Vulnerability: Self-Study's Contribution to Social Justice Education". Perspectives in Education 32 (2): 89-101.

Knowles, C. 2014b. "Shaking Foundations: Teaching and Learning in the Extended Studies Programme". Unpublished final portfolio submitted for the PG(Dip) HE.

Knowles, C. 2020. "Thanks Malaika for this: 'emotion is not lack of reason. The insistence on treating emotion as mutually exclusive from reason is rooted in Westernised formulations of what constitutes valid knowledge and what doesn't'. Facebook, November 12, 2020. Accessed October 6, 2021. https://www.facebook.com/corinne.knowles.3/posts/10157265842211557.

Kraak, A., ed. 2000. Changing Modes: New Knowledge Production and Its Implications for Higher Education in South Africa. Pretoria: HSRC Press.

Lewis, D. 2001. “African Feminisms”. Agenda: Empowering Women for Gender Equity 16 (50): 4-10.

Lewis, D. 2010. "Discursive Challenges for African Feminisms". In African Feminist Politics of Knowledge: Tensions, Challenges, Possibilities, edited by S. Arnfred and A. Adomako Ampofo, 205-21. Uppsala: Nordic Africa Institute. 
Linden, A. 2017. “Unemployed Graduates in 'Flash Mob' Protests”. Dispatch Online, February 23, 2017. Accessed June 6, 2018. https://www.dispatchlive.co.za/news/2017-02-23unemployed-graduates-in-flash-mobprotests/?fbclid=IwAR34EQzzyFbnMi3DdkDYAFbrLB25Z6d2hFOQSPokJwfJG7WV4e_ DjwvbpOo.

Lundgren, N., and M. Prah. 2010. "Disappearing Dodos? Reflections on Women and Academic Freedom Based on Experiences in Ghana and the United States". In African Feminist Politics of Knowledge: Tensions, Challenges, Possibilities, edited by A. Adomako Ampofo and S. Arnfred, 157-86. Uppsala: Nordic Africa Institute.

Mahlangu, B. 2012. "Interviewing Bantu Biko-Extracts from His Quotes". News24, September 12, 2012. Accessed January 13, 2019.

https://www.news24.com/MyNews24/Interviewing-Bantu-Biko-Extracts-from-his-Quotes20120912.

Mama, A. 2011. "The Challenges of Feminism: Gender, Ethics and Responsible Academic Freedom in African Universities". Journal of Higher Education in Africa/Revue de l'enseignement supérieur en Afrique 9 (1-2): 1-23.

Mama, A. 2020. "Africa Talks: The Future of African Feminist Activism”. Webinar hosted by the London School of Economics and Political Science. Accessed November 11, 2020. https://www.lse.ac.uk/Events/2020/11/202011121400/africa.

Masola, A. 2018. "Women Who Wrote Themselves into History". Nal'ibali (blog), August 29, 2018. Accessed June 12, 2018. https://nalibali.org/women-who-wrote-themselves-intohistory\#.

Matthews, S. 2011. "Becoming African: Debating Post-Apartheid White South African Identities". African Identities 9 (1): 1-17. https://doi.org/10.1080/14725843.2011.530440.

McLaren, J. I., and F. W. Struwig. 2019. "Financial Ratios as Indicators of Financial Sustainability at a South African University". Journal of Contemporary Management 16 (2): 68-93. https://doi.org/10.35683/jcm19030.0027.

Mekgwe, P. 2007. “Theorizing African Feminism(s). The 'Colonial' Question”. Matatu 35 (1): 165-74. https://doi.org/10.1163/9789401205641_011.

Mkabela, Q. 2005. "Using the Afrocentric Method in Researching Indigenous African Culture". The Qualitative Report 10 (1): 178-89.

Mkhize, N. 2015. "Tenacious Belief in the Ideal of the University". Business Day, May 5, 2015. Accessed June 6, 2018. https://www.businesslive.co.za/bd/opinion/columnists/201505-05-tenacious-belief-in-the-ideal-of-the-university/.

Moletsane, R. 2015. "Whose Knowledge Is It? Towards Reordering Knowledge Production and Dissemination in the Global South". Educational Research for Social Change (ERSC) 4 (2): 35-47. 
Moloi, K., M. W. Makgoba, and C. O. Miruka. 2017. “(De)Constructing the\# FeesMustFall Campaign in South African Higher Education". Contemporary Education Dialogue 14 (2): 211-23. https://doi.org/10.1177/0973184917716999.

Motlafi, N. 2015. "Why Black Women in South Africa Don't Fully Embrace the Feminist Discourse". The Conversation, August 7, 2015. Accessed October 1, 2021. https://theconversation.com/why-black-women-in-south-africa-dont-fully-embrace-thefeminist-discourse-45116.

Ngcobozi, L. 2015. "RhodesSoWhite: An Insight". The Conmag, March 27, 2015. Accessed June 5, 2018. http://www.theconmag.co.za/2015/03/27/rhodessowhite-an-insight/.

Ntseane, P. G. 2011. "Culturally Sensitive Transformational Learning: Incorporating the Afrocentric Paradigm and African Feminism”. Adult Education Quarterly 61 (4): 307-23. https://doi.org/10.1177/0741713610389781.

Oyěwùmí, O. 1997. The Invention of Women: Making an African Sense of Western Gender Discourses. Minneapolis, MS: University of Minnesota Press.

Pather, S. 2018. "South Africa: The High Drop Out Rate of First-Year University Students". Inside Education, March 23, 2018. Accessed November 3, 2021.

https://www.insideeducation.org/featured/south-africa-high-drop-rate-first-year-universitystudents/.

Salami, M. 2013. “A Brief History of African Feminism”. Ms Afropolitan (blog), July 2, 2013. Accessed January 10, 2020. https:/www.msafropolitan.com/2013/07/a-brief-history-ofafrican-feminism.html.

Salami, M. 2017. "What Is African Feminism, Actually?” Ms Afropolitan (blog), December 7, 2017. Accessed June 5, 2020. https://www.msafropolitan.com/2017/12/what-is-africanfeminism-actually.html.

Salo, E., and A. Mama. 2001. "Talking about Feminism in Africa”. In Agenda: Empowering Women for Gender Equity 16 (50): 58-63.

Skade, T. 2016. "Black Graduates, Mainly Women, at Highest Risk of Unemployment". Destiny Man. Accessed November 20, 2018. https://destinyman.com/2016/04/05/womenand-black-graduates-face-highest-unemploymentrisk/?fbclid=IwAR0scvniGRwEeZXpZPSC6GwnRtVgKq5Dhdv7U4E75Ba0Cub7cXLmb pgEvzE.

Tamale, S. 2020. Decolonization and Afro-Feminism. Ottawa: Daraja Press.

Tamale, S., and J. Oloka-Onyango. 1995. “"The Personal Is Political', or Why Women's Rights Are Indeed Human Rights: An African Perspective on International Feminism”. Human Rights Quarterly 17 (4): 691-731. https://doi.org/10.1353/hrq.1995.0037. 
Wa Azania, M. 2020. Corridors of Death: The Struggle to Exist in Historically White Institutions. Polokwane: Blackbird Books.

Wane, N. N. 2008. "Mapping the Field of Indigenous Knowledges in Anti-Colonial Discourse: A Transformative Journey in Education". Race Ethnicity and Education 11 (2): 183-97. https://doi.org/10.1080/13613320600807667.

Wils, L. 2017. "Gender, Sexuality and Transformation in Higher Education". Mail \& Guardian, September 29, 2017. Accessed October 23, 2018. https://mg.co.za/article/201709-29-00-gender-sexualithy-and-transformation-in-higher-education. 